\title{
Manuel Godoy w roli ojca
}

Manuel Godoy (1767 - 1851), premier Hiszpanii, faworyt hiszpańskiej pary królewskiej, Karola IV i Marii Ludwiki, w historiografii przedstawiany jest zwykle jako polityk, dyplomata i mąż stanu ${ }^{1}$. Stosunkowo niewiele miejsca poświęca się jego działalności na polu gospodarki, kultury, oświaty. Bardzo mało wiemy o życiu prywatnym faworyta, które jest ukazywane w ciemnych kolorach. We współczesnej literaturze hiszpańsko-francuskiej, od kilkunastu lat zauważamy dążenia do rehabilitacji tej jednej $z$ najbardziej kontrowersyjnych postaci w historii Hiszpanii. Jednak nadal wiele aspektów jego życia pozostaje słabo rozpoznana. Do zagadnień wymagających gruntownych badań należy m.in. problem: jakim Godoy był ojcem.

Nasze rozważania będą oparte glównie na korespondencji Godoya prowadzonej w latach $1817-1820$ z jego intymną przyjciółka, późniejsza żona, Josefa Tudó, zwaną zdrobniale Pepitą lub Pepa. Korespondencja ta jest przechowywana w Archivo Histórico Nacional w Madrycie. Część listów została opublikowana w całości lub we fragmentach w kilku artykułach poświęconych losom Godoya po odsunięciu go od władzy w 1808 roku $^{2}$. Jednak żaden z historyków nie wykorzystał ich do rozważań nad życiem rodzinnym Godoya.

Kiedy Godoy obejmował urząd premiera (1792) był młody, przystojny i cieszył się wielkim powodzeniem wśród kobiet. Sprawa musiala być głośna skoro po Madrycie krążyły uszczypliwe wierszyki na temat jego romansów, zwłaszcza z Pepitą ${ }^{3}$. Publiczną tajemnica było, że miał on również intymne zwiazki z królowa. Przypisywano mu nawet ojcostwo dwóch najmłodszych dzieci królewskich, tj. infantki Izabeli i infanta Fanciszka de Paula Antonio. Do dzisiaj wśród historyków brak zgodności $w$ tej kwestii ${ }^{4}$. Godoy nie ukrywał swych podbojów miłosnych. W liście do Karola IV, obok sprawozdania $\mathrm{z}$ pracy $\mathrm{w}$ ministerstwie, umieścił wzmiankę: „Rano $\mathrm{w}$ poniedziałki, środy, soboty udzielam audiencji publicznych dla ludzi, zaś w środy noca kobietom, które tłumnie przybywaja na spotkanie ze mna"s.

W takiej sytuacji Maria Ludwika, aby położyć kres plotkom i obronić własny autorytet zmusiła Godoya do slubu z krewną króla, Maria Teresą de Borbón y Villabriga, hrabina de Chinchón (1797)6. Po trzech latach małżeństwo doczekało się córki Szarloty. Sprawując urząd pierwszego ministra,

' O działalności polityczno-dyplomatycznej, a zwłaszcza o polityce zagranicznej Manuela Godoya zob. B. Obtułowicz, Ksiazę Pokoju księciem wojny. Polityka Manuela Godoya wobec Francji w latach 1792 - 1808 , Kraków 1999.

2 Np. J. Pérez de Guzmán, La rehabilitación del Principe de la Paz, „La Ilustración Española y Americana”, 1907, nr 2; tenże, La historia inédita. Estudios de la vida, reinado, proscripción y muerte de Carlos IV y Maria Luisa de Borbón reyes de España, Madryt 1909, różne strony; M.L.V. Las alhajas de la Reina Maria Luisa: Una intriga de la Tudó, „Hispania”, Madryt, 1943, s. $138-152$.

${ }^{3}$ Np. (Anonim), Poesías patrióticas (...). Versos salíricos contra Godoy, incluidos en un Sermón pronunciado por un compañero del mismo apellido, Biblioteca Nacional en Madrid, sección Raros, rkps., R 62695, f. 4; Joseph de Orga, De Godoy y Bonaparte, Quién de los dos es peor? Letrilla, Biblioteca Nacional en Madrid, Valencia 1808, sección Raros, R 60034/34; (Anonim), Preguntas de la justicia a Godoy, 1808 (druk ulotny), Boblioteca Naciona! en Madrid, sala Cervantes, R/62606.

${ }^{4}$ B. Obtułowicz, op. cit., s. 47.

5 Archivo General de Palacio, Papeles Reservados de Fernando VII, t. 102, folio 71, Manuel Godoy do Karola IV, San Lorenzo, 22.11.1795.

' L.G. Santos, Godoy Principe de la Paz. Siervo de la guerra, Madryt 1985, s. 75; A. Salcedo Ruiz, La época de Goya, Madryt 1939, s. 179. 
a następnie najwyższego zwierzchnika sił lądowych i morskich, Godoy tak bardzo był zajęty sprawami politycznymi, że niewiele czasu mógl poświęcić dla rodziny. $Z$ drugiej strony nadal utrzymywał kontakt z Pepita, z którą miał dwóch synów: Manuela i Ludwika. Współczesny Godoyowi ekonomista i polityk hiszpański, Gaspar Melchor Jovellanos, pisał, że premier bez skrępowania zapraszał Pepitę na przyjęcia wyznaczając przy stole miejsce tuż obok Marii Teresy ${ }^{7}$. Jeśli wierzyé relacjom posła duńskiego w Madrycie Hermana de Schubart oraz pisarzowi hiszpańskiemu José Blanco White Godoy publicznie pokazywał się z Pepa w karocy ${ }^{8}$, zaś w skrytości przed świadkami jadał z nią wspólnie kolacje i rozmawiał do późnych godzin nocnych ${ }^{9}$. Dowiadując się o tym Maria Ludwika płonęła ze złości i z zazdrości zarazem. Z myślą o uniknięciu skandalu obyczajowego królowa nadała Pepie tytuł hrabiny de Castillofiel i przyjęła do grona dam dworu ${ }^{10}$. Od tej pory obie panie, tj. oficjalna żona Godoya i jego kochanka należały do najbliższego otoczenia hiszpańskiej pary królewskiej. Po rewolucji w Aranjuez (marzec 1808), która definitywnie odsunęła Godoya od władzy, zaś Karola IV i Ferdynanda VII zmusiła do oddania korony rodzinie Bonapartych (w Bajonnie w maju 1808), faworyt towarzyszył swym królewskim protektorom na wygnaniu najpierw we Francji (Fontainebleau, Compiegne, Marsylia), potem w Italii (Rzym). W skromnym dworze exmonarchów znalazły się Josefa z synami oraz Szarlota, nad którą Maria Ludwika, jako chrzestna matka roztoczyła troskliwą opiekę. Maria Teresa nie podażyła za mężem. Pozostala w Hiszpanii u swgo brata, biskupa Toledo. W tym miejscu warto nadmienić, że wiadomość o obecności Szarloty w orszaku udającym się z Bajonny do Fontainebleau, dotarła na ziemie polskie. Wzmiankowały o niej „Gazeta Krakowska”" oraz "Gazeta Korespondenta Warszawskiego i Zagranicznego"'2. Godoyowi nie na długo dane było cieszyć się bliskością dzieci. Ferdynand VII, który po abdykacji Napoleona w 1814 roku i po ucieczce Józefa I z Madrytu odzyskał tron hiszpański, oddzielił Pepitę wraz z synami od Godoya nakazując wyjazd najpierw do Pizy, a następnie do Genui. Miał to być odwet za rzekome dażenia Godoya, jeszcze przed 1808 rokiem, do odebrania mu korony. W rezultacie powyższej decyzji przez najbliższe lata Godoy pozostawał z synami i Pepita jedynie w kontakcie listowym. W 1818 roku w Pizie zmarł chory na gruźlicę młodszy syn Ludwik. W 1820 Szarlota uzyskała od Ferdynanda VII pozwolenie na powrót do kraju, gdzie rok później wyszła za mąż za księcia Kamila Rúspoli. W 1827 dwudziestodwuletni Manuel ożenił się z Angielką, niejaka panna Mary Crove. Po śmierci Marii Teresy Godoy wział ślub z Josefa w Rzymie (1829) i po trzech latach oboje osiedlili się w Paryżu. W stolicy Francji spędzili razem jedynie dwa lata. W 1834 za akceptacja męża Pepa wyjechała do Hiszpanii, aby tam kontynuować starania na rzecz odzyskania dóbr i godności odebranych Godoyowi w dobie rewolucji w Aranjuez. Od tej pory Godoy pozostał sam z dala od syna, córki i drugiej żony.

Życic Godoya oraz okres, w którym jego dzieci przychodziły na świat i dorastały to epoka wielkich przełomów wyznaczanych przez: Oświecenie, rewolucję francuska, epokę napoleońska, narodziny liberalizmu i Romantyzmu. Postanowienia Kongresu Wiedeńskiego, zmieniając mapę Europy i powracając do starego, absolutystycznego systemu rządów prowokowały mieszkańców kontynentu do walki o wolność, równość i niepodleglość. Hiszpania znalazła się poza zasięgiem walk narodowo-wyzwoleńczych. W pierwszej połowie XIX wieku przeżywała własne problemy. Wojna o niepodległość (1808-1814) spowodowała wprawdzie ogromne straty materialne i ludzkie, ale stworzyła korzystne warunki dla działalności sił liberalnych. Jednak młody król Ferdynand VII, wbrew woli znacznej części społeczeństwa restaurował rządy absolutne. Polożenie Hiszpanii dodatkowo pogarszały trudności gospodarcze i postępujacy proces rozpadu jej imperium zamorskiego. Odcięcie metropolii od dostaw szlachetnych kruszców sukcesywnie zubożało skarb zmuszając rząd do zaciagania długów zagranicznych. Z myślą o ratowaniu stanu finansów państwa Ferdynand VII sprzedał Florydę Stanom

\footnotetext{
${ }^{7}$ B. Obtułowicz, op. cit., s. 78.

${ }^{8}$ H. de Schubart, Lettres d'un diplomate dannois en Espagne 1798-1800, „Revue Hispanique”, t. IX, 1902,

9 J.B. White, Cartas de España, Madryt 1986, s. 254-255.

${ }^{10}$ L.G. Santos, op. cit., s. 75; A. Salcedo Ruiz, op. cit., s. 179.

11 "Gazeta Krakowska", nr 49. 19.06.1808, s. 578: nr 50. 22.06.1808, s. 590.

12 "Gazeta Korespondenta Warszawskiego i Zagranicznego", nr 51, 25.06.1808, s. 668.
} s. 403 . 
Zjednoczonym za jedyne 5 tysięcy dolarów, za co te odwdzięczyły się uznaniem niepodległości Argentyny, Boliwii i Chile. W takich warunkach Hiszpania szybko przestawała się liczyć na arenie międzynarodowej spadając do poziomu drugorzędnego. Po 1815 roku stawała się peryferią Europy, terenem rozgrywek politycznych między Francja a Anglią ${ }^{13}$. Decyzje kongresowe miały natomiast dotkliwe następstwa dla Półwyspu Apenińskiego, który aż do lat sześćdziesiątych XIX wieku stanowił teren nieustannych działań na rzecz zjednoczenia w jedno państwo. Tak więc okres, w którym Godoy i Pepita prowadzili ze soba ożywioną korespondencję zarówno dla Półwyspu Apenińskiego, jak i Pirenejskiego był czasem pełnym niepokojów. Jednocześnie szybko zmieniająca się scena polityczna, ideologiczna i ekonomiczna inspirowala przeobrażenia w pozostałych sferach życia. Przemiany te nie ominęły zagadnień zwiazanych $\mathrm{z}$ szeroko pojętym modelem rodziny, miejscem $\mathrm{i}$ rolą ojca $\mathrm{w}$ rodzinie.

Historia ojców i ojcostwa opracowana pod redakcja historyków francuskich dokonała szczegółowej charakterystyki cech typowych dla ojców epoki przechodzenia od starego reżimu do społeczeństwa liberalnego ${ }^{14}$. W tym kontekście warto zastanowić się na jle Godoy odbiegał od naszkicowanych tam stereotypów. Trzeba pamiętać, że sytuacja Godoya w roli ojca była specyficzna ponieważ:

1) oprócz legalnej córki mial dwóch synów ze związku pozamałżeńskiego,

2) jako wieloletni mąż stanu i polityk, który w sojuszu z Napoleonem prowadził wojny z Anglia należał do osób znanych w całej Europic,

3) przed 1808 rokiem ze względów politycznych wraz z dziećmi i Pepa przebywał poza krajem ojczystym na wygnaniu,

4) przez kilka lat był oddzielony od synów.

Fakty te sprawiały, że Godoy nie należał do grona ojców ,przeciętnych”, zwłaszcza ze względu na swa przeszłość i jej konsekwencje w postaci wygnania i separacji. Jednak gdyby nie rozłąka z synami i Josefa nie mielibyśmy tak bogatego materiału źródłowego jakim sa listy, które w znakomity sposób ułatwiaja opracowanie omawianego tematu.

Przełom XVIII/XIX wieków to „,epoka patriarchów”, czyli dominacji i wszechobecności ojca w życiu prywatnym. Bez względu na przynależność rodziny do określonej grupy społecznej ojciec (włościanin, rzemieślnik, robotnik, kupiec, arystokrata, przedsiębiorca itd.) czuwał nad wszystkim, kierował praca, rozdzielał żywność i sankcje, narzucał decyzje i prawa domownikom, był surowym zwierzchnikiem, zamkniętym w sobie, absolutnym panem swego potomstwa ${ }^{15}$. Godoy nie należał do ojców władczych i patriarchalnych, jakich przedstawiala literatura epoki Oświecenia na czele z Nowa Helioza Jana Jakuba Rousseau. Przed 1808 rokiem bardzo mało interesował się dziećmi oddając je w ręce ich matek. Podczas pobytu we Francji i w Rzymie Szarlota zajmowala się królowa i damy dworu, zaś Manuelem i Ludwikiem Pepa. Zmiana nastapiła, w przypadku Szarloty po śmierci królowej (1819), zaś synów po wygnaniu Pepy z Rzymu (1814). Wtedy przejął on bezpośrednia pieczę nad córka i współodpowiedzialność za losy synów. Należy podkreślić, że w świetle analizowanych listów, jeśli sprawa dotyczyła synów, Godoy nigdy do niczego nie zmuszał Pepy. To ona jako matka miała decydujacy głos. Godoy jedynie służył rada i sugerował rozwiazania.

Charakterystyczną cechą Oświecenia była troska o wykształcenie i wychowanie mlodych pokoleń. Godoy, chociaż sam wyrastał i kształtował się w duchu ideałów Oświecenia i będąc u władzy uchodził za jednego z ilustrados (człowieka oświeconego), wbrew zaleceniom J.J. Rousseau zawartym w Emilu, nie brał czynnego udziału w edukacji swych dzieci. Dlaczego? W przypadku Manuela i Ludwika odpowiedź jest oczywista: nie mieszkał z nimi. Z korespondencji z Pepitą wynika, że pomimo oddalenia bardzo zależało mu na zapewnieniu synom solidnego wykształcenia, jako gwaranta lepszego startu w dorosłe życie. „Moim największym marzeniem jest, aby mój syn odebrał dobre wychowanie

${ }^{13}$ O postępującej izolacji i zacofaniu Hiszpanii w pierwszej połowie XIX wieku zob.:J. Kieniewicz, Hiszpania 1814-1844. Koniec "starego tadu" i poczatki zacofania, [w:] Europa i swiat w epoce restauracji, romantyzmu i rewolucji 1815-1849, t. I, Warszawa 1991, s. 365-398; H.R. Madol, Godoy: el primer dictador de nuestro tiempo, Madryt 1987, s. 254-255.

i4 Historia ojców $i$ ojcostwa, pod red. Jeana Delumeau i Daniela Rochea, Warszawa 1995, s. $233-323$.

${ }^{15}$ Tamże, s. 323. 
i wykształcenie oraz potrafił pokierować sam soba" ${ }^{16}$. Pragnienie to nasiliło się po smierci Ludwika. Od tej pory kwestia wykształcenia Manuela jeszcze mocniej polączyła Godoya i Pepe, stajac się przedmiotem dyskusji, wzajemnej wymiany spostrzeżeń, dominujacym tematem listów. Główny ciężar opieki nad Manuelem spadał na matkę, ale Godoy w miarę możliwości starał się jej ulżyć. Obok doraźnej tylko pomocy materialnej przesyłał Pepie wskazówki dotyczace spraw wychowawczych. Apelowal o zachowanie rozwagi przy doborze towarzystwa dla Manuela ${ }^{17}$, chwalił za zakupienie synowi strzelby, aby za młodu nauczył się posługiwania bronia palną niezbędną m.in. podczas polowań ${ }^{18}$, zalecał odbywanie konsultacji $\mathrm{z}$ doświadczonymi wychowawcami ${ }^{19} \mathrm{i}$ usilnie prosił, aby Manuel: ,nie zrobił sobie w czym krzywdy ${ }^{20}$, nie zszedł na manowce ${ }^{21}$, nie wpadł w złe ręce" ${ }^{22}$. Dzięki listom Pepity Godoy miał doskonała orientację w rozwoju fizycznym i intelektualnym syna. Wiedział, że wyrastał na przystojenego młodzieńca ${ }^{23}$, który zaczynał się oglądać za dziewczętami ${ }^{24}$ oraz, że pod względem fizjonomii i charakteru do złudzenia przypominal swego ojca ${ }^{25}$. Z drugiej strony w sposobie bycia i w psychice zachował jeszcze wiele cech dziecka ${ }^{26}$. Chłopiec był odważny, ruchliwy, ciekawy świata i miał dobre serce ${ }^{27}$. Ku zmartwieniu obojga rodziców Manuel nie garnął się do nauki. Z tym większą ostrożnością Josefa dobierała guwernerów spośród ludzi wymagajacych i przesyłała Godoyowi do wglądu skrócone programy nauczania Manuela prosząc o zaopiniowanie ${ }^{28}$. „Mam wiadomość o wielkich zdolnościach nowego preceptora Manuela, pisał Godoy do Pepity, i że nakłaniacie go do stosowania wobec naszego syna nadzwyczajnych metod. Skadinad wiem, że młodzi ludzie [aluzja do owego guwernera - BO] nie lubia, gdy rodzice ingeruja w metody kształcenia przez nich stosowane". W tym samym liście Godoy ostrzegał Pepę, że zbyt częste wtrącanie się do edukacji prowadzonej przez kompetentne osoby może mieć fatalny wpływ na wrażliwą psychikę ucznia, który wchodził w trudny wiek dojrzewania ${ }^{29}$. Kontynuując ten watek Godoy radził swej przyjaciółce zatrudnianie kilku nauczycieli, co miało podwyższyć poziom nauczania ${ }^{30}$. Najlepszy sposób na pobudzenie u Manuela zainteresowania nauką upatrywał w nawiązaniu przez niego szczerej przyjaźni $z$ nauczycielem. Cala sprawa do tego stopnia absorbowała Godoya, że pisał o niej osobny list do syna ${ }^{31}$ i nocami rozmyślal, jak ułożą się stosunki między Manuelem a jego utalentowanym guwernerem ${ }^{32}$.

Niewatpliwie tak mocne zaangażowanie Godoya w edukację Manuela wynikało nie tylko ze zwykłej ojcowskiej troski. Jako premier i zaufany doradca Karola IV i Marii Ludwiki zdobył dobra orientację o stanie oświaty hiszpańskiej. Zdając sobie sprawę z jej zapaści próbował ratować, poprzez zwiększenie liczby placówek oświatowych, reformę szkół średnich i uniwersytetów, wprowadzenie powszechnego nauczania na szczeblu podstawowym oraz popularyzację nowych metod edukacji. Był wtedy goracym zwolennikiem poglądów pedagogicznych Jana Henryka Pestalozziego. Opracowany przez Pestalozziego system edukacyjny po raz pierwszy został zastosowany dzięki inicjatywie Godoya

${ }^{16}$ Archivo Histórico Nacional, Estado, legajo (dalej cyt. AHN) 2832, Manuel Godoy do Pepity Tudó, Albano, 16.09.1818.

17 AHN, 2834, Manuel Godoy do Pepity Tudó, Rzym, 5.08.1819.

18 Ibidem, 14.10.1819.

19 Ibidem, 20.11.1819.

${ }^{20}$ Ibidem, 14.10.1819.

21 Ibidem, 5.08.1819.

23 Ibidem, 8.05.1819.

23 AHN, 2833, Pepita Tudó do Manuela Godoya, Piza, 17.10.1817; AHN, 2834, Pepita Tudó do Manuela Godoya, Genua, 31.07, 18.08.1819; AHN, 2836, Pepita Tudó do Manuela Godoya, Genua, 9.02.1820.

24 AHN, 2834, Pepita Tudó do Manuela Godoya, Genua, 1.05.1819.

25 AHN, 2833, Pepita Tudó do Manuela Godoya, Piza, 13.10., 3.11.1817; AHN, 2834, Pepita Tudó do Manuela Godoya, Genua, 14, 31.07.1819; tamże Manuel Godoy do Pepity Tudó, Rzym, 27.05., 7.06., 22.07.1819.

${ }^{26}$ AHN, 2833, Pepita Tudó do Manuela Godoya, Piza, 15.10.1817.

27 AHN, 2834, Pepita Tudó do Manuela Godoya, Genua, 13.03.1819.

28 Ibidem, 26.12.1819.

29 Ibidem, 23.09.1818.

30 Ibidem, 27.09.1818.

${ }^{31}$ Ibidem, 30.09.1818.

32 Ibidem, 2.10.1818. 
w jednej ze szkół madryckich utworzonej w 1806 roku. Wkrótce podobne szkoły powstały w innych rejonach Hiszpanii ${ }^{\natural 3}$. W oparciu o analizowana korespondencję należy wnosić, że Manuel odebrał edukację tradycyjna, która niewiele miała wspólnego z systemem Pestalozziego. Według relacji Pepy pod okiem dobrych historyków uczył się historii starożytnej Grecji i Rzymu. Brał również lekcje łaciny, ortografii i religii, ale najbardziej lubił matematykę i geometrię ${ }^{34}$. Nie miał zacięcia humanistycznego. Mimo to, matka zmuszala go do czytania literatury pięknej, poezji klasycznej i nauki pamięciowej ${ }^{35}$. Działała więc nie tylko wbrew opinii Godoya, który uważał, że syn powinien doskonalić się w tym, $w$ czym robi największe postępy ${ }^{36}$, ale niezgodnie z postulatami Pestalozziego. Szwajcarski uczony twierdzit, że nauczanie powinno być dostosowane do spontanicznego rozwoju i zainteresowań dziecka. Duża wagę przywiazywał do kształcenia umysłu poprzez wyrabianie samodzielnego myślenia zdolnego do formuowania własnych ocen $\mathrm{i}$ opinii, a nie na drodze ćwiczeń pamięciowych. $\mathrm{W}$ jednym tylko można by się dopatrywać zbieżności między kształceniem Manuela a modelem propagowanym przez szwajcarskiego pedagoga. Otóż Tudó pragnęla, aby syn uzupełnił edukację domową nauką w jednym z renomowanych kolegiów zagranicznych. Pod uwage brala Szwajcarię, gdzie jeszcze żył Pestalozzi i Francje, której stolica uchodziła za centrum nauki i kultury europejskiej ${ }^{37}$. Były to jednak propozycje samej Pepy. Omawiana korespondencja ujawnia co o nich sadził Godoy.

Odnośnje edukacji Szarloty to podobnie jak w przypadku Manuela powierzył ja prywatnym guwernerom, u których pobierała: „lekcje muzyki i innych przedmiotów" ${ }^{38}$. Nic więcej nie wiemy na ten temat. Skoro jednak Godoy w przypadku syna akceptował tradycyjny model kształcenia, nie należy sądzić, aby wobec córki zastosował inny, zwłaszcza, że w ówczesnych czasach do edukacji kobiet nie przywiązywano większej wagi. Wychodząc z takiego założenia możemy przypuszczać, że ,inne przedmioty" obejmowały: taniec, śpiew, język francuski, pisanie, czytanie, liczenie, robótki ręczne. W przeciwieństwie do paryskiego rytownika Philona, ojca przyszłej pani Roland ${ }^{39}$ Godoy nie dysponował wystarczającym kapitałem, aby zapewnić córce wysoka kulturę ogólną i artystyczną. Starał się zrekompensować ten brak i jak wiemy, po śmierci Marii Ludwiki przejął na siebie obowiazzki zwiazane z opieką i wychowaniem córki. ..Służę jej za kamerdynera, chodzimy razem na spacery i do teatru" ${ }^{40}$, relacjonował Pepicie, która z Szarlotą łączyły szczere więzy przyjaźni. W listach czytamy, że podczas codziennych przechadzek odbywanych $w$ towarzystwie córki, Godoy rozmawiał $z$ nia na rozmaite tematy. Przeważały wśród nich wpomnienia $\mathrm{z}$ dawnych lat i plany na przyszłość ${ }^{41}$. Ponadto często urządzali przejażdżki odkrytymi powozami ${ }^{42}$ i odwiedzali znajomych ${ }^{43}$.

Godoyowi podobał się rozmach, jaki Pepa chciała nadać edukacji syna, ale musial jej przypominać: „snując plany edukacji Manuela miej na uwadze nasze możliwości finansowe" Niestety te ostatnie kurczyły się gwałtownie z miesiąca na miesiąc. Przyczyn trzeba szukać m.in. w rewolucji w Aranjuez (1808), w wyniku której Godoy został pozbawiony całego majatku. Podczas pobytu we Francji i Italii Godoy, Pepita wraz z rodzina oraz Szarlota, podobnie jak pozostali członkowie dworu exmonarchów hiszpańskich, żyli ze skromnych sum, które skapy Ferdynand VII przesyłał rodzicom. Po śmierci Karola IV i Marii Ludwiki (styczeń 1819) król nieodwołalnie zniósł pomoc materialna, stawiajac wszystkich w dramatycznej sytuacji. Tak więc Godoy nie spełniał obowiazku wedlug prawa zwyczajowego zaliczanego do podstawowych powinności rodzicielskich,

\footnotetext{
${ }^{33}$ B. Obtulowicz, op. cit., s. 182.

34 AHN, 2833, Pepita Tudó do Manuela Godoya, Piza, 6.10.1817.

35 AHN, 2834, Pepita Tudó do Manuela Godoya, Genua, 9.08.1819.

36 Ibidem, Manuel Godoy do Pepity Tudó, Rzym, 6.01.1820.

37 Ibidem, Pepita Tudó do Manuela Godoya, Genua, 30.08.1819; AHN, 2836, Pepita Tudó do Tuncana (kuzyn Pepy mieszkajacy w Paryżu), Genua, 4,03.1820.

${ }^{38}$ AHN, 2834, Manuel Godoy do Pepity Tudó, Rzym, 16.02.1819.

${ }^{39}$ Historia ojców i ojcostwa, op. cit., s. 274.

40 AHN, 2834, Manuel Godoy do Pepity Tudó, Rzym, 3.05.1819

41 Ibidem, 3.07.1819.

42 Ibidem, 8.11.1819.

${ }^{43}$ Ibidem, 29.09.1819.

44 Ibidem, 9.09.1819.
} 
ponieważ nie potrafil zapewnić dzieciom utrzymania. Sa jednak dowody, na to, że miał ambicję pełnienia roli ojca - żywiciela. Z dążeniem do realizacji tego pragnienia należy łączyć starania o restytucję utraconego majątku, jakie podjął wspólnie z Pepita tuż po śmierci ich królewskich protektorów. Póki co korzystał z zabezpieczenia finansowego zostawionego mu przez Karola IV i Marię Ludwikę, dzięki któremu mógł jeszcze przez pewien czas utrzymywać siebię, córkę, Pepę, Manuela, a nawet rodziny sióstr Pepity ${ }^{43}$.

Problem rehabilitacji byłego premiera zaplatał się z kwestią prawnej regulacji jego ojcostwa. Dla Szarloty Godoy był prawowitym ojcem, dla Ludwika i Manuela jedynie biologicznym. Kłopoty finansowe nakazywały Godoyowi pilne uporządkowanie tej sytuacji. Jeszcze za życia Karola IV i Marii Ludwiki Godoy zabiegał o unieważnienie małżeństwa z Maria Teresą i o poślubienie Josefy ${ }^{46}$, dzięki czemu zostałoby uznane jego ojcostwo wobec Ludwika i Manuela. Gdyby równocześnie Ferdynand VII oddał Godoyowi majatek, wtedy obaj synowie uzyskaliby takie samo prawo do sukcesji, jakie przysługiwało Szarlocie. Niestety, udało mu się to zrealizować dopiero po wielu latach.

Godoy był ojcem sprawiedliwym. W 1818 roku podczas ostrej zimy i panującej w związku z nia epidemii grypy ciężko zachorował na malarię. Chwilami myślał, że umrze i wtedy napisał swój pierwszy testament. Nie znamy dokładnej treści tego aktu ostatniej woli. Jednak z informacji zebranych z listów Godoya wynika, że poczynił on zapis ze swych niewysokich oszczędności zarówno na córkę, jak na syna ${ }^{47}$, chociaż $w$ obliczu prawa jako dziecko nieślubne nie miał powołania do dziedziczenia po swym naturalnym ojcu.

Godoy odstawał od modnego wówczas stereotypu ojca surowego, zimnego, małomównego, wymagajacego. Nie korzystał z prawa karcenia, przyznanego ojcom przez napoleoński kodeks cywilny ${ }^{48}$. W stosunku do dzieci i Pepy okazywał wielką troskliwość i wyrozumiałość. Podczas przewlekłej choroby Ludwika drźał o życie syna ciesząc się z każdej, nawet najmniejsza poprawa i rozpaczając w okresach kryzysów ${ }^{49}$. Z myślą o złagodzeniu cierpień małemu „męczennikowi”, jego bratu i matce, wysylał z Rzymu do Pizy prezenty w postaci ubrań, koni do ujeżdżania ${ }^{50}$ itp. Równie glęboko przeżywał wszelkie niedyspozycje i dolegliwości Szarloty, zawsze wierząc $w$ jej szybki powrót do zdrowia ${ }^{51}$. Nie ukrywał swych uczuć. Podczas każdej rozłakki z synami tęsknił za nimi. Pisała o tym nawet „Gazeta Krakowska” zamieszczajac w 1808 roku opis reakcji Godoya na otrzymanie listu od Karola IV, kiedy znajdował się $w$ drodze do Bajonny. Podobno Godoy przyjał list $z$ wielka wdzięcznością skarżąc się na samotność, opuszczenie przez wszystkich, pozbawienie dóbr, tytułów i wygnanie $\mathrm{z}$ ojczyzny. Na koniec, $\mathrm{z}$ goryczą wyraził wielkie pragnienie spędzenia reszty życia w otoczeniu swych dzieci ${ }^{52}$. „Jeśli kiedyś zobaczę moje ukochane dzieci - wyznawal Pepie dziewięć lat później - umrę z radości”" ${ }^{3}$. Twoje listy, zwracał się do Manuela, „są dla mnie ukojeniem, leczą smutek mej duszy, czytając je nie potrafię powstrzymać łez"54. Ze swej strony pocieszał tęskniacego syna nadzieją wspólnego spotkania ${ }^{55}$. W odpowiedzi na zarzuty Pepy dotyczące zbyt łagodnego traktowania syna, Godoy tłumaczył się brakiem bezpośredniego kontaktu z Manuelem i wielką do niego miłością, która nie pozwalała na krytyczne uwagi, wymierzanie kar ani udzielanie nagan ${ }^{56}$. „Gdybym go miał przy sobie, gdybyśmy mieszkali razem - przekonywał Pepę - na pewno potrafiłbym trzymać go krócej" ${ }^{57}$. W zestawieniu z wypowiedziami Godoya na temat metod wychowawczych, jakie on sam

\footnotetext{
${ }^{45}$ Ibidem, 13, 17.05., 3.06., 8.07. 1819.

4 J.Pérez de Guzmán, La historia iédita. Estudios de la vida..., s. 13-18, 28 i nast.

${ }_{47}$ AHN, 2834, Socorro [siostra Pepy] do Pepity Tudó i Cataliny [ich matki], Rzym, 30.01.1819, nr 3.

48 Historia ojców $i$ ojcostwa, op. cit., s. 303.

49 AHN, 2833, Manuel Godoy do Pepity Tudó, Rzym, 3, 13, 15. 11.1817.

50 Ibidem, I5, 17, 20, 22, 24.11.1817.

51 AHN, 2834, Manuel Godoy do Pepity Tud6, Rzym, 8.11.1819.

52 „Gazeta Krakowska”, nr 44, 1.06.1808, s. 521.

53 AHN, 2833, Manuel Godoy do Pepity Tudó, Rzym, 1, 6.12.1817.

${ }^{54}$ AHN, 2832, Manuel Godoy do syna Manuela, Rzym, 10.12.1818.

ss Ibidem, Manuel Godoy do Pepity Tudó, Albano, 7.12.1818; tamże, Rzym 10.12.1818.

56 Ibidem, Albano, 2, 7.10.1818.

$\$ 7$ Ibidem, Albano, 7.10.1818.
} 
stosował wobec córki, z którą widywał się codziennie, argumentacja ta nie jest przekonywująca. Jeśli wierzyć temu co pisał do Pepy, to Szarlota miała dużą swobodę w postępowaniu. Kochajacy ojciec w zasadzie niczego jej nie zabranial: „Pozwalam córce na wszystko, aby była zadowolona" 58 .

Godoy był ojcem ofiarnym, zdolnym do ponoszenia osobistych cierpień, niewygód, byle tylko dać radość i szczęście dzieciom. Po śmierci pary królewskiej, siostry Josefy (Socorro i Magdalena) wraz ze swymi rodzinami oraz Godoy z córka musieli opuścić zajmowany dotychczas pałac Barberinich. Wszyscy przenieśli się do rzymskiej willi Campitelli, która swego czasu zakupił Godoy, a nastẹpnie podarował w prezencie mężowi Socorro, markizowi Stefanoni. W budynku panowała ogromna ciasnota. Godoy donosił Pepie, że z braku gotówki nie może wynająć większego lokum i dlatego wymienił się pokojami z Szarlota odstępując jej pomieszczenje o większym metrażu ${ }^{59}$. W między czasie rozglądał się za nowym, w miarę tanim mieszkaniem i wprowadził drastyczne oszczędności: zlikwidował służbę, zajmował się zakupami, gotowaniem, sprzątaniem, praniem ${ }^{60}$. Nie żałował pieniędzy jedynie dla córki: kupowal jej nowe stroje, książki, opłacał guwernerów ${ }^{61}$. Sam przyznawał, że pobyt w Campitelli pomimo wielu minusów miał również dobre strony. Do plusów zaliczał fakt, że $w$ otoczeniu rodzin sióstr Pepy oraz znajomych, którzy przybywali do nich z różnych stron miasta, Szarlota miała kontakt z szerokim światem i nie odczuwała samotności ${ }^{62}$. Ofiarność Godoya przejawiała się również w tym, że ulegając prośbom córki robił coś czego sam nie lubił. Do tego typu zajęć należały częste wizyty w teatrze. Nudzil go nie teatr co wystawiane w nim tragedie, ,ale bawia one Szarlotę - tłumaczył Pepie - dlatego mam cierpliwość, aby je wytrzymać do momentu aż spuszczą kurtynę"63.

W świetle powyższych wywodów okazuje się, że Godoy, o którym na przestrzeni dwóch wieków napisano tyle negatywnych opinii, w rzeczywistości był dobrym ojcem szczerze kochającym swe dzieci. Występujac w roli ojca wyrozumiałego, czułego, gotowego do poświęceń, łagodnego, wykraczał poza sztywne ramy stereotypów ojców: władczych, wymagających, surowych, wyrachowanych, propagowanych przez ówczesną literaturę. Żyjac w okresie, kiedy w Europie ścierały się rozmaite nurty polityczne, ekonomiczne, kulturalne, religijne, Godoy nosił w swej osobowości cechy typowe dla dwóch epok: Oświecenia i Romantyzmu. W młodości, piastując urząd premiera oraz funkcje najwyższego dowódcy sił lądowych i morskich Hiszpanii,wyróżniał się energia, niezwykła pracowitością, uporem w dążeniu do zakładanych celów. Na pierwszym miejscu stawiał dobro państwa i dynastii. Wszystko inne, w tym rodzina, w hierarchii jego wartości leżały na dalszym planie. Rewolucja w Aranjuez, inwazja wojsk napoleońskich na Półwysep Pirenejski wyznaczyły nowy etap w życiu Godoya. Z osoby publicznej, nagle stał się osobą prywatna, która w dodatku szybko chciała zapomnieć o swej burzliwej przeszłości. Cały jego świat zamknał się w kręgu spraw rodzinnych oraz zabiegów o odzyskanie utraconych tytulów, godności i majątów. Najbardziej cenił spokój, refleksję, czytanie ksiażek, rozmowy i przechadzki z córką, pisanie listów do swej ukochanej i ich synów. „Unikam ludzi - pisal do Pepy - kontakty utrzymuję tylko z grzeczności, kiedy spotykam znajomych na ulicy” "64. „Przedkladam samotność nad przebywanie w elitarnym towarzystwie, [...] ponieważ zbyt długo musiałem dzień i noc znosić ludzi, cierpieć z ich powodu, aby teraz prowadzić ożywione życie towarzyskie. Poprzestaje więc na czytaniu ksiażek i w ten sposób spędzam czas do późnych godzin nocnych, zwłaszcza wtedy, gdy nie ma teatru" ${ }^{65}$. Tak więc widzimy, że w drugiej połowie swego długiego życia Godoy z racjonalnego i pragmatycznego człowieka Oświecenia stał się romantykiem. Ta nagła zmiana stanowiła rezultat wielu czynników, do których poza faktem odsunięcia Godoya od władzy i skazaniem na wygnanie, należy dołączyć zmiany w jego stanie psychicznym i fizycznym. Godoy zmęczony piętnastolenią „kadencja" na szczytach wladzy, coraz częściej zapadajacy na zdrowiu, podświadomie szukał pociechy

\footnotetext{
${ }^{58}$ AHN, 2834, Manuel Godoy do Pepity Tudó, Rzym, 8.11.1819.

${ }^{59}$ Ibidem, 26.06, 12.07.1819.

${ }^{60}$ Ibidem, 10.06, 5.07.1819.

${ }^{61}$ Ibidem, 13.05.1819.

62 Ibidem, 3.05. 1819.

${ }^{63}$ Ibidem, 29.09.1819.

64 Ibidem, 10.07.1819.

65 Ibidem, 15.11.1819.
} 
w kręgu rodzinnym. Wierzył głęboko, że jeżeli zadba o wychowanie swych dzieci, to one mu się za to odwdzięcza "na stare lata"66. Stało się jednak inaczej i na tym polegał tragizm Godoya jako ojca. Godoy boleśnie odczuł tę prawdę, kiedy po wyjeździe Pepy z Paryża (1834) pozostał sam. Nikt się nim wówczas nie interesował i na dodatek cierpiał upokarzająca biedę. Podobno najlepiej czuł się w otoczeniu dzieci z ulicy, z którymi rozmawial, brał je na kolana, pozwalał dotykać swej laski i siedzac na lawce całymi godzinami obserwowal jak się bawią ${ }^{67}$. Godoy zawsze darzył sympatia dzieci. Obce kochał niemal jak swoje. Udowodnił to jeszcze w Rzymie, po przeprowadzce do willi Campitelii. W stosunkowo małym domu zamieszkałym przez kilka rodzin pokornie znosil nie tylko ciasnotę, ale obecność trzech rozbrykanych synów Magdaleny Tudó. „Mieszkają nad moim pokojem i nie mogę nie słyszeć gier, biegów i krzyków, jakie wydobywają z siebie - narzekał do Pepy, ale zaraz potem dodawał ze spokojem: - rozumiem, to zupełnie naturalne w ich wieku" ${ }^{68}$. Jego wrażliwość wobec potomstwa sióstr Pepy (Socorro i Magdaleny) szła tak daleko, że znając trudną sytuację materialną rodziców partycypowal w kosztach ich utrzymania ${ }^{64}$.

\section{Wizerunek matki prezentowany przez Klementynę z Tańskich Hoffmanową na łamach pisma "Rozrywki dla dzieci”}

Artykuł ten jest próba przedstawienia wizerunku matki, jaki stworzyła swoja ręką Klementyna z Tańskich Hoffmanowa, i który przedstawiła na łamach wydawanego przez siebie pisma pt. Rozrywki dla Dzieci. Zanim jednak zaprezentujemy wizerunek', czyli opiszemy słowami postać matki nakreślony przez Hoffmanowa, należy poddać analizie warunki społeczno-polityczne, jakie wpłynęły na ukształtowanie się tegoż wizerunku w spoleczeństwie polskim w XIX wieku.

Niewatpliwie obraz matki w tym czasie był w znacznym stopniu lustrzanym odbiciem idealu kobiety, jaki wytworzył się w mentalności społecznej na przestrzeni XIX wieku. Miejsce i rolę kobiety w społeczeństwie w tym czasie wyznaczały jej obowiazki i funkcje wynikające $\mathrm{z}$ jej powołania, tj. żony - wiemej towarzyszki mężczyzny, wzorowej gospodyni zarządzającej domem i wychowujacej dzieci matki. Powszechny w tym czasie pogląd, że opatrzność i sama natura wskazywała tej połowie rodu ludzkiego jej właściwe powołanie, kształtował ideał kobiety wyposażonej w takie cechy i zalety charakteru, jak miłość, wiemosśc, skromność, pobożność, gospodarność, dbałosć o dom i rodzinę ${ }^{2}$. Wymienione cechy i zalety tworzace obraz ideału kobiety, były jednocześnie wykładnikiem wzorowej żony i matki. Zbudowany w oparciu o ten ideał wizerunek matki, to wrażliwa, ciepła, skromna, pobożna i rozsądnie myśląca kobieta, świadoma swej społecznej roli, postępowaniem służąca za przykład dla swoich dzieci. Zwłaszcza jeśli chodzi o córki, matka miała świecić przykładem i w ten sposób przygotować je do przyszłej roli żony i matki. Warunki historyczne nałożyły na kobietę dodatkowo rolę

\footnotetext{
${ }^{66} \mathrm{AHN}, 2832$, Manuel Godoy do Pepity Tudó, Rzym, 19.12.1818.

${ }^{67}$ E. Rúspoli y Morenés, La marca de exilio. La Beltraneja, Cardoso y Godoy, Madryt 1992, s. 192-221.

${ }_{68}$ AHN, 2834, Manuel Godoy do Pepity Tudó, Rzym, 8.07.1819.

69 Ibidem, 8.07.1819.

I WIZERUNEK [w:] Maty slownik jezzyka polskiego, wyd. IX, Warszawa 1993, s. 899.

${ }^{2}$ D. Rzepniewska, Kobieta w rodzinie ziemianískiej w XIX wieku Królestwo Polskie, [w:] Kobieta i spoleczenistwo na ziemiach polskich w XIX wieku, pod red. A. Żamowskiej i A. Szwarca, Warszawa 1990, s. 38.
} 